\title{
Identity and Cultural Recognition in the Curriculum: A Rationale
}

\author{
Khawlah Ahmed \\ American University of Sharjah, College of Arts and Social Sciences, English \\ Department, Sharjah, UAE, P.O. Box 26666 \\ e-mail: khawlah@aus.edu
}

\begin{abstract}
Culture has become an important component that is addressed in a variety of contexts from the teaching of a language (Baker, 2003), educational equality (Gay, 1997; 2000), to politics and cultural identities (Llosa, 2008; Muller, 2008; Goshgarian, 1998). Empirical and theoretical research shows that students perform better and are more academically and socially successful when their culture is recognized, portrayed favorably in the school curriculum, and used as a fundamental source of information (Nieto, 1996; Diamond and Moore, 1995; Au, 1993; Geyhle, 1983). This paper examines the importance of inclusion and recognition of cultures in school curriculums and presents research that suggests that despite the importance given to this issue in political and social discourse, inclusion of cultures in many curriculums has yet to be fully realized.
\end{abstract}

Key words: culture, identity, literacy, curriculum, recognition, schooling

What happens when someone with the authority of teacher describes the society that the student is in and you [the student] are not in it? (Rich as cited in Takaki, 1993, p. 14).

The issue of recognition and inclusion of different ethnic/minority groups by what is known as the 'dominant' group has been an issue that has long been prevalent in most parts of the world where different cultural groups are forced to live and co-exist with one another. This issue has resurfaced recently in many parts of today's globalized world. In countries where many different ethnic groups are forced to live together, such as in the U.S. which has been described as the "the most multicultural nation" that knows "less than most nations about the world from which [its] people come from” (Baker, 2008, p. 269), this issue has prevailed throughout its history, since the beginning of immigration into the U.S. (Seller, 1992, 1988) and continues to do so today. 
In all parts of the world minority groups continue to revive these issues and demand their recognition and inclusion in society. In education, this recognition (whether symbolic or not) has taken the form of what is now known as multicultural education. And many large minority groups, such as African Americans, Hispanics, and Asians in the U.S., are slowly beginning to be recognized and their once silent voices are beginning to be heard in literature. An abundance of literature is being produced about these different groups including information which deals with many aspects of their students' educational experiences, learning styles, cultural values, and principles (e.g., Ogbu, 1991; Nieto, 1996). However, even today there are a number of minority groups which are still 'invisible' to a great extent and remain a mysterious part of their societies (Nieto, 1996; Suleiman, 1996; Banks, 1995; Uphall, 1974). The many factors, whether in the school or societal curriculum, that may be affecting students' experience, in particular students who come from minority cultures, have not as of yet, been given their fair share of research and have been left, to a great extent, at the schoolhouse doors.

The role of today's powerful media, a powerful tool which has the ability to shape the attitudes of individuals and groups (Thomas, et. al, 2004; Gardner, 1991; Reynolds, 1991), attitudes which are carried into the classroom, is one of these factors. Among the many aspects that can be deemed important in relation to the media, is the language used, especially ethnic labels, which can perpetuate prejudice (Thomas et al., 2004) and cause discrimination among the different ethnic groups. The representations portrayed by the media, whether in news or movies, work to construct the media's own systems of meaning, social organization and their own cultural identification (Giroux, 1994). These representations, or 'ideological constructs', according to Giroux (1994), serve to mobilize particular cultural practices and are 'highly pedagogical' in their attempt to produce specific knowledge values, and desires. What is more, "viewers [students included] directly absorb the ideological messages [consistent with the interest of the state] conveyed by a particular film or signifying practice" (Giroux, 1988, p. 24) which can have negative consequences not only for those being portrayed, but on viewers as well.

The characteristics that are attributed to a group of people, or students in this case, have been shown to end up becoming a 'deficiency' that is associated with that particular group (Shujaa, 1995). The group soon becomes projected as a minority group whose members are seen as 
"deficient human beings-people who have little or no self- esteem or who lack knowledge of themselves" (p.199). Soon everything around these minority members, or students, begins to give them the impression that they are "devalued human-beings" because according to Shujaa's argument (1995), their "cultural history has been omitted from school knowledge or distorted by it" (p.199) and reinforced by the image portrayed about them whether in the media or elsewhere. Students who are in situations like this are intentionally or unintentionally placed in a mental hole from which it might be very difficult to get out. "Realities" have been appropriated for them and their levels of self-esteem and selfimage may begin to accommodate and reflect the image that has been set for them (Kambon, 1992, in Shujaa, 1995).

With all these aspects to contend with, curriculum and pedagogy have been mostly based on what is described by Nieto (1996) as an alien and imposed reality instead of the lived experiences that these students may be going through. The pain, alienation, isolation, and rejection that many minority children might be facing are rarely being confronted in schools. They have traditionally perceived their roles as that of an assimilating agent (Banks, 1981; Nieto, 1996), and to a great extent, still continues to do so.

\section{ALLOWING CULTURES TO BECOME VISIBLE}

Whether it is described as a term that was "commonly used as a synonym for Western civilization" in the $19^{\text {th }}$ century (Jandt, 2007, p. 6), or as "one of the most contentious concepts in academia" in the second half of the $20^{\text {th }}$ century, culture is still "very much a burning issue at the beginning of the $21^{\text {st }}$ century" (Atkinson, 2004, p. 279) and will continue to be a "burning issue" because culture is very important to those who identify with it. From an anthropological perspective, culture is defined as "the ever-changing values, traditions, social and political relationships, and world view created and shared by a group of people bound together by a combination of factors that can include a common history, geographic location, language, social class, and or religion” (Nieto, 1996, p. 138). Each person maintains an image of the behaviors, beliefs and norms (i.e. culture) appropriate to members of the ethnic group which is known as a cultural identity (Ferdman, 1990).

Research suggests that students' cultures, histories and experiences need to be made visible by making them part of the curriculum, and of 
education in general. Inclusion and representation of cultures have been shown by empirical research to have important, if not crucial, consequences for students, both on the social and academic level. Educators understand the effects that recognition of culture and cultural identity can have, particularly on students. Theoretical research suggests that when authority figures, such as teachers, exclude certain cultural groups from the curriculum, it has devastating effects on the students who belong to those cultures. They describe this effect on the student as a moment of "psychic disequilibrium" as if the student "looked into a mirror and saw nothing”" (Takaki, 1993, p. 14). Not being included and recognized can be interpreted personally as not existing, not worthy to be included, or just plain powerless.

Educators and community leaders need to recognize the importance of culture on students' lives. Recognition and inclusion preserve languages and cultures. They assert the intrinsic and cultural values of the different languages, as well as legitimate their heritage in the eyes of others. This legitimization, according to Seller (1992), "perpetuates" ethnic identity among children and is "potential in giving tone to the individualization of youth", and increases the children's respect for their parents (p. 13). This perpetuation of ethnic identity not only brings about consciousness of one's ancestry, but may have other influences. According to a Norwegian novelist, "young people who were cut off from the culture of their parents lacked creativity as well as character" (Seller, 1992, p. 13). Recognition and inclusion of cultures not only preserves cultures, but can instill a sense of pride and ethnic identity in children who will learn that "their collective pasts extended beyond the squalid tenements to glories of ancient civilizations and the achievements of great scholars, artists, and kings" (Seller, 1988, p. 159).

This identity and pride in one's self and cultural heritage can have psychological effects on individuals. From a social psychological perspective, it gives people a sense of belonging to group membership (Ferdman, 1990). It answers the important question 'Who am 1?' (Gordon and Browne, 1996), and legitimates one's existence in the eyes of others. This legitimization becomes quite important, especially if one is from a minority group which is devalued and demeaned (Suleiman, 1996; Wright, 1995).

Empirical research shows that in general, students perform better and are more academically and socially successful when their culture is 
recognized, portrayed favorably in the school curriculum, and used as a fundamental source of information and may feel that whatever is not valued by school is not worth learning (Nieto, 1996; Au, 1993; Diamond and Moore, 1995). Theory and literary portrayals suggest that many problems can arise when students with strong cultural identities and backgrounds do not see their cultures in the school curriculum. Not seeing this culture acknowledged can result in conflicts leaving the student disillusioned and possibly torn apart between the two conflicting cultures, that of the home and that of the school (Takaki, 1993). This can be a result of not seeing one's culture being presented or because what is presented about one student's culture can be different from, or foreign, to what the student has been presented with or taught at home (Ladson-Billings, 1994; Banks, 1995; Nieto, 1996). No where are the effects of this devaluing and non-recognition more powerfully expressed than in Nieto's (1996) case study of the Hispanic student Rodriguez, who described his childhood as a "myth" because his school and private life could not be reconciled. Due to the devaluing of his culture in school, Rodriguez decided to give up his language, culture and to some extent family to become 'successful'. The consequences that Rodriguez had to pay were great. He had to make the painful choice "between family and school...what inevitably becomes the choice between belonging and succeeding” (p. 3). Miller and McCaskill (1993) also present accounts of students' experiences and the consequences or the price that students have had to pay for keeping their cultures in contexts where those cultures were ignored, mocked or left behind. Historically these students have "learned that at the core of American schools functions an either/or proposition: either students must discard their indigenous cultures, or they will be excluded” (p. 3).

\section{CULTURAL LINKS TO ACADEMIC SUCCESS}

Cultural identity plays an important role in the nature and outcome of the intergroup comparisons that the group makes, which in turn may lead to the way the group comes to evaluate itself (Ferdman, 1987; Montero, 1987 in Ferdman, 1990; Tajfel \& Turner, 1986). Seeing oneself portrayed and recognized, gives the student a sense of belonging and pride which in turn can motivate students to learn and become or feel successful. Evidence of this relationship has been shown in research (Au, 1981; Gay, 1995). The importance of recognition and culture on students' academic success has 
been explained in many studies (Suleiman, 1996; Nieto, 1996; Hoffman, 1996; Banks, 1995; Takaki, 1993). Two highly successful intervention programs provide illustration of the positive effects of teaching that recognizes students' cultures and experiences. The first is the KEEP (Kamehameha Early Education Program) program for native Hawaiian students. This program matched the styles used to teach reading and language arts skills with native Hawaiian cultural styles of learning, communicating and interacting. It succeeded in radically reversing the low levels of academic achievement for the participating students (Au, 1981). The second was a study conducted by Jaime Escalante which demonstrated how Mexican-American students were able to dramatically improve in their math skills when teaching was culturally compatible to their instructional and learning styles (Gay, 1995). The participants' cultures in both of these studies were allowed 'to speak,' as Gay says, in their cultural ways, and also about their cultures.

Culturally relevant pedagogy uses methods of teaching which have been described as culturally appropriate (Au, 1981). Culturally relevant teaching also allows students to 'see' their culture being present in the curriculum, which in turn assists in the development of personalities that allow students from these cultures to become academically successful and still identify with their culture. Therefore, it empowers students emotionally, socially, and intellectually to transcend the negative portrayals of their home cultures by the dominant culture (Ladson-Billings, 1994).

The connection between recognition of culture and literacy involves not only the culture and literacy that the students learn at home, but the culture and literacy that is involved with schools. Literacy, school achievement and the culture that the students identify with (in the home or at school) are closely related (Ferdman, 1990). Schools are viewed as the institutions most responsible for literacy education and socialization in a society (Apple, 1996; Applebee, 1974). In many cases, literacy education tends to be left primarily to the school. As a result, many children become literate in the cultural images represented by their school. In this respect it can be assumed that literacy education can constitute a form of socialization. Learning becomes synonymous with the unquestioned acquiring and absorbing not only of skills, but also of the behaviors, values, and principles of the school culture which is usually that of the white middle class (Walsh, 1991). Whether it is deliberate or not, the process of 
becoming and being literate in school involves becoming and being identified with a particular culture, the culture of the school.

Because the student has already been socialized by the culture of the home and community (Vygotsky, 1978, 1986), a problem can arise especially if what the student has already learned clashes with the school culture. Comparative analysis of cultural differences has been shown to exist between minority cultures and the school culture. These differences have been shown to be of major importance to the educational experiences of the students involved. Examples of differences which may hinder the students' academic success include cognitive, interactional, and learning styles (Ogbu, 1991).

Most students come to school with positive expectations of their ability to learn and be successful regardless of their cultural background. But if faced with non-recognition, or misconceptions and stereotypes, students may be highly affected by these misconceptions to the point that students (as well as teachers) begin to believe that they are not capable of achieving success. According to Shujaa (1995), the nature of a group of people's experiences in U.S. society and the process of schooling need to be brought into question. In the African American students' situation, Shujaa believes that the students' behaviors (and in a way their academic and social success) in schools "are responses to schooling as a process of formal socialization that aims to shape their understandings of the world in accordance with the interests of the elite within the social hierarchy" (p.197). The African American students' failure in school might be due to the failure of the socialization process. In a study of high school students conducted by Hidalgo (in Nieto, 1996), and a study on teacher perceptions conducted by Shujaa (1995), it was shown that school, social success, and the issue of self-esteem are created within particular contexts and respond to conditions that are due to social factors. It was shown that teachers' and schools' complicity in creating negative portrayals cannot be discounted.

Because literacy is a culturally defined construct, and because children become literate in the cultural image represented by their home and school, "it follows that it [1iteracy] should have close links to cultural identity" (Ferdman, 1990, p. 194). Culture and literacy are "intertwined with the meaning and consequences of becoming and being literate" (p. 182). According to Ferdman, "when a child perceives a writing task, or text, and its symbolic contents as belonging to and reaffirming his or her cultural identity, it is more likely that he or she will become engaged [in the task] 
and individual meaning will be transmitted or derived” (p. 195). But when the "tasks and symbols that serve to deny or to devalue aspects of the individual's cultural identity, or even those that are neutral in relation to it may be approached differently and with less personal involvement” (p. 195).

The link between culture and achievement has been emphasized by research that suggests that improvement in learning, including basic skills, can be expected when instruction is compatible with the cultural patterns acquired at home. The incorporation of language and culture into the school curriculum can constitute a significant predictor of academic success. For example, in reading instruction, students' life experiences and cultural background influence the degree of comprehension and memory that students achieve (Mason and Au, 1990 in Diamond and Moore, 1995). Diamond and Moore (1995) conclude that "the essence of students" prior experience and culture-their ways of interacting, communicating, celebrating, and experiencing life-combine to form their initial understanding of the world" (p. 8). And 'to facilitate learning' for these students, learning needs to be compatible with and emerge from their culture, their traditions, and their heritage" (p. 8).

The theoretical and empirical research, based largely on a sociocultural perspective on literacy, reviewed by Diamond and Moore (1995), shows that students who learn to draw from their personal experiences, who receive information based on their cultural backgrounds, are taught to form hypotheses, make association, organize and store information based on their background knowledge and who learn to connect this knowledge to their reading and writing, become powerful and accomplished learners. This is probably because, as Giroux (1987) explains, a person's stories, narratives and readings of the world are inextricably associated with and related to the wider social and cultural formations and categories. Different ways of reading, writing, listening and viewing are determined within broader social and cultural formations which contain what can be understood and said about social identity (Giroux, 1994). What is meant by this, from a sociocultural perspective, is that certain things presented in the social and or cultural levels, can become internalized by the individual's mind (Vygotsky, 1986). Through language, messages, symbols and so forth, we begin to internalize ideas about ourselves and others (Gudykunst, 1994). And, as Giroux (1994) explains further, "knowledge and social identities are produced in a variety of sites including schools" (p. 132). The 
messages we hear can influence our minds. It is for this reason that what is portrayed in the 'hidden curriculum' of the school and society, can be just as effective as what is presented in the formal school curriculum (Giroux, 1987). What is meant here by 'hidden curriculum' is the ways in which students or different cultural groups are sorted out, categorized, and represented mostly in negative ways, in the school as well as the social settings in a subtle manner by virtue of ethnicity, race, or other characteristics: "People find themselves often positioned within forms of knowledge, institutional structures, and social relationships that have a “creeping or quiet” kind of hegemony about them” (Giroux, 1994, p. 157). Sometimes people are made to inhabit 'spaces' that shape their identity in a particularly harmful way, according to Giroux (1994).

It is important to legitimate students' experiences, and help students to speak with a voice that is rooted in their sense of history and place (Giroux, 1994). In the context of literacy education, a lot has to do with what the student experiences as being 'owned' or 'not owned' by him/her and or the group he/she identifies with (Ferdman, 1990). That which the student associates with will be more relevant, meaningful, and will be more engaging and motivating. This will lead to more understanding, and therefore, to better chances of success. And that which is not culturally relevant and meaningful, will be approached with less personal involvement and less motivation.

\section{FROM THEORY TO PRACTICE}

All of this sounds very promising but what does this mean in terms of recognition and inclusion in the curriculum, i.e. course design, material writing, material selection and or adaptation, and teaching methodology, and has such rhetoric and research made its way into today's curriculum? In societies where governments stress unity, inclusion and recognition of all the different groups and ethnicities found in society, a curriculum needs to be 'multicultural.' According to Lie (2002), this kind of curriculum needs to incorporate the following broad goals: contain material that would help students develop positive gender, racial, cultural, class, religious, and individual identities and would recognize and accept their membership in many different groups; allow students to see themselves as part of the larger society and to empathize and relate to individuals from other groups within that society; fosters respect and appreciation for differences, 
promote the development of a sense of shared humanity, and support the development of educational and social skills for students to become full participants in the larger society in ways that are most appropriate to individual styles, cultural orientations, and linguistic backgrounds. A 'true multicultural curriculum' needs to integrate cultural contexts throughout subjects and grade levels (Diaz, 2001). Ramsey (1987, as cited in Lie, 2002) sees that multicultural education "is not a set curriculum but a perspective that is reflected in all decisions about every phase and aspect of teaching. It is a lens through which teachers can scrutinize their choices in order to clarify what societal information they are conveying overtly and covertly to their students” (p. 43). The goals of a multicultural curriculum may have indirect or short term effect on the larger societal and economic problems that trigger intergroup tension, but they can influence the ways that the new generations interpret and participate in social relationships (Lie, 2002).

Calls for inclusion in the form of 'multicultural education' dated back to the 70 's. Yet at the beginning of the $21^{\text {st }}$ century, even in the most democratic of countries like the U.S., avenues are still being searched for and efforts are still being made to include cultures/ethnicities in the curriculum and encourage educators to alter current teaching practices to teach content using multicultural perspectives (Diaz, 2001). And despite the fact that calls for inclusion began with the beginning of U.S. history, and despite the changes in demographics in the U.S. and the coming about of multicultural education about four decades ago, in the U.S., according to Diaz, Anglo and Eurocentric curriculum still prevail in schools, and the information portraying other cultures that has been included is still 'ghettotized' (p. 2). In Indonesia, Lie (2002) found that though the government stresses unity and the fact that diversity should not be neglected, her research into the English language curriculum being used in public schools shows that the curriculum still does.

In countries like the Arab world globalization and changes in educational policies are beginning to take their toll on the native Arabic language and culture. Concerns are being voiced about sidelining this language and marginalizing its culture especially in some of the societies in the Arab Gulf where the natives comprise only about $10 \%$ of the population (see Mills, 2008; Krieger, 2008). Yet in reviewing a sample of textbooks from the ESL/EFL curriculum taught in the public schools in one of these Gulf countries to see to what degree this native culture is 
represented in the curriculum (the distribution of ethnicity between the local native Arab culture and non-Arab culture), the results found were not in favor of the native culture.

\section{CONCLUSION}

The impact of literacy education which has a socialization effect on the student and which does not consider the student's cultural identity can be harmful to some extent. When a person loses the capability to derive and create meaning in a culturally significant way, that person becomes less literate, not more so (Ferdman, 1990). It may be that successful learning, as defined by some schools' points of view, forces the ethnic minority child to become disconnected to what he feels, or has grown up to associate with as personally significant. As a result, his or her ability to construct a positive and coherent cultural identity will be weakened. The costs of developing doubt about one's worth and dignity is an unusually high price that minority students may have to pay (Nieto, 1996). By not presenting and acknowledging the cultures and cultural identities of students, schools may not just be hindering their academic success, but they may be insisting on 'wiping out' a very important part of their existence (Nieto, 1996).

In education, the issue of inclusion and recognition has lead to what is known as multicultural education. But while many honest efforts are being exerted to incorporate less dominant cultures, it seems that these efforts have only partially seen their way into many curriculums around the world. The social and political discourses and policies may advocate inclusion and show concerns of the over-dominance of some cultures and the alienation of indigenous or less powerful ones, but curriculums have yet to fully reflect these concerns.

\section{REFERENCES}

Apple, M. W. (1996). Cultural politics and education. New York: Teachers College Press.

Applebee, A. (1974). Tradition and reforming the teaching of English: A history. Urbana: National Council of Teachers of English.

Atkinson, D. (2004). Contrasting rhetorics/contrasting cultures: Why contrastive rhetoric needs a better conceptualization of culture. Journal of English for Academic Purposes, 3, 277-289. 
Au, K. H. (1981). Participant structure in a reading lesson with Hawaiian children: Analysis of a culturally appropriate instrument. Anthropology and Education Quarterly, 10(2), 9-15.

Au, K. H. (1993). Literacy instruction in multicultural settings. USA: Bolt, Rinehart and Winston.

Baker, B. (2008). The educated student: Global citizen or global consumer? In G. H. Muller (Ed.), The new world reader: Thinking and writing about the global community (2 ${ }^{\text {nd }}$ ed.) (pp. 295-303). New York: Houghton Mifflin Company.

Banks, J. A. (1995). Multicultural education: Characteristics and goals. In J. A. Banks, \& C. Banks (Eds.), Multicultural education: Issues and perspectives (pp. 3-28). Needham Heights, Massachusetts: Allyn and Bacon.

Diamond. B., \& Moore, M. (1995). Multicultural literacy: Mirroring the reality of the classroom. New York: Longman Publishers.

Diaz, C. (Ed.). (2001). Multicultural education in the $21^{\text {st }}$ century. New York: Longman.

Ferdman, B. (1990). Literacy and cultural identity. Harvard Educational Review, 60(2), 181-204.

Gardner, R. (1991). Attitudes and acculturation in second language studying. In A. Reynolds (Ed.), Bilingualism, multiculturalism, and second language learning (pp. 43-63). Hillsdate, New Jersey: Lawrence Earlbaum Associates.

Gay, G. (1995). Mirror images on common issues: Parallels between multicultural education and critical pedagogy. In C. Sleeter, \& E. McLaren (Eds.), Multicultural education, critical pedagogy, and the politics of difference (pp. 155-190). Albany, New York: State University of New York Press.

Gay, G. (1997). Educational equality for students of color. In J. A. Banks, \& C. A. Banks (Eds.), Multicultural education: Issues and perspectives (pp.195228). Hoboken, New Jersey: Wiley.

Gay, G. (2000). Culturally responsive teaching: Theory, research and practice. New York: Teachers College Press.

Giroux, H. A. (1987). Critical literacy and student experience: Donald Graves’ approach to literacy. Language Arts, 64, 175-181.

Giroux. H. A. (1988). Schooling and the struggle for public life: Critical pedagogy in the modem age. Minnesota: University of Minnesota Press. 
Giroux, H. A. (1994). Disturbing pleasures. Great Britain: Rutledge.

Gordon, A., \& Browne, K. (1996). Guiding young children in a diverse society. Needham Heights, Massachusetts: Allyn and Bacon.

Goshgarian, G. (1998). Exploring language. New York: Longman.

Gudykunst, W. (1994). Bridging differences: Effective intergroup communication. Thousand Oaks California: SAGE Publications.

Hoffman, D. (1996). Culture and self in multicultural education: Reflections on discourse, text and practice. American Educational Research Journal, 33(3), 545-569.

Jandt, F. E. (2007). An introduction to intercultural communication: Identities in a global community ( $5^{\text {th }}$ ed.). Thousand Oaks, California: Sage Publications.

Krieger, Z. (2008, March 7). An academic building bloom transforms the Persian Gulf. Chronicle of Higher Education, 54(29), p. B.

Ladson-Billings, G. (1994). The dream keepers: Successful teachers of African American children. San Francisco: Jossey-Bass.

Lie, A. (2002). Multicultural issues in the 1994 English curriculum in Indonesian senior high schools. Singapore: SEAMEO Regional Language Center Singapore.

Llosa, M. V. (2008). The culture of liberty. In G. H. Muller (Ed.), The new world reader: Thinking and writing about the global community ( $2^{\text {nd }}$ ed.) (pp. 295303). New York: Houghton Mifflin Company.

Miller, S., \& McCaskill, B. (Eds.). (1993). Multicultural literature and literacies: Making space for differences. Albany, New York: State University of New York Press.

Mills, A. (2008, Sep).Emirates look to the West for prestige, Chronicle of Higher Education, 55(5), A1.

Muller, G. H., (2008). The new world reader: Thinking and writing about the global community. Boston: Houghton Mifflin Company.

Nieto, S. (1996). Affirming diversity: The sociopolitical context of multicultural education. New York: Longman Publishers USA.

Ogbu. J. (1991). Cultural diversity and school experiences. In C. Walsh (Ed.), Literacy as praxis: Culture, language and pedagogy. Norwood, New Jersey: Ablex Publishing Corporation. 
Reynolds, A. (1991). Bilingualism, multiculturalism, and second language learning. Hilisdale, New Jersey: Lawrence Earlbaum Associates.

Seller, M. S. (1988). To seek America: A history of ethnic life in the United States. Englewood. New Jersey: Jorome S. Ozer.

Seller, M. S. (1992). Historical perspectives on multicultural education: What kind? By whom? For whom? And why? Social Science Records, 30, 11-30.

Shujaa, W. (1995, Summer). Cultural self meets cultural other in the African American experience: Teachers' responses to a curriculum content reform. Theory into Practice, 34(3), 194-201.

Suleiman, M. (1996). Educating the Arab American child: Implications for teachers. (Eric Document Reproduction Service No. ED 392864).

Tajfel, H., \& Turner, J. (1986). The social identity theory of intergroup relations. In S. Worchel, \& W. Austin (Eds.), The psychology of intergroup relations (pp.7- 24). Chicago: Nelson-Hall Publishers.

Takaki, R. (1993). A different mirror: A history of multicultural America. Canada: Little, Brown and Company.

Thomas, L., Wareing, S., Singh, I., Peccei, J. S., Thomborrow, J., \& Jones, J. (2004). Language society and power ( $2^{\text {nd }}$ ed.). London: Routledge.

Uphall, J. K. (1974). Religious minorities: In or out of the culturally pluralistic curriculum. Educational Leadership, 33(3), 199-202.

Vygotsky, L. S. (1978). Mind in society: The development of higher psychological processes. Cambridge, Massachusetts: Harvard University Press.

Vygotsky, L. S. (1986). Thought and language. Cambridge, Massachusetts: The Mit Press.

Walsh, C. (1991). Literacy as praxis: A framework and an introduction. In C. Walsh (Ed.), Literacy as praxis: Culture, language and pedagogy. Norwood, New Jersey: Ablex Publishing.

Wright, J. W. (1995). Social distance, discrimination, and political conflict: Arabethnics in America. The Journal of Intergroup Relations 21(4), 3-11. 